\title{
EGDMA-cross-linked polystyrene resin: An efficient support for gel phase peptide synthesis
}

\author{
P K AJIKUMAR and K S DEVAKY* \\ School of Chemical Sciences, Mahatma Gandhi University, \\ Priyadarshini Hills, Kottayam 686 560, India \\ e-mail: mgu@md2.vsnl.net.in
}

MS received 30 June 1999; revised 17 January 2000

\begin{abstract}
This article illustrates the application of a $2 \%$ ethyleneglycol dimethacrylate-cross-linked polystyrene support (EGDMA-PS) in manual solid phase peptide synthesis. This copolymer has been characterised and optimised for peptide synthesis by performing the synthesis of a few model peptides and two biologically important peptides. EGDMA-cross-linked polystyrene support was prepared by the suspension polymerisation of the monomers EGDMA and styrene. EGDMA-PS resin undergoes facile swelling in a variety of solvents, both polar and nonpolar, used in peptide synthesis. The polymer was functionalised by Friedel-Crafts chloromethylation reaction. Peptides were assembled on a $2 \%$ cross-linked chloromethyl polymer support of capacity $1.63 \mathrm{mmol} \mathrm{Cl/g}$. The biological peptides synthesised are an 11 residue peptide ATP binding site of the CDC2 kinase and a difficult sequence-a nineresidue peptide $\beta 34-42$ corresponding to a portion of the hydrophobic terminus of the $\beta$-amyloid protein $\beta$ 1-42. After synthesis, the peptides were cleaved from the support by treating with neat TFA. Purity of the peptides obtained in good yield was checked by TLC and HPLC methods and found to be fairly high.
\end{abstract}

Keywords. Solid-phase peptide synthesis; EGDMA-PS supports.

\section{Introduction}

Ever since the introduction of solid-phase peptide synthesis ${ }^{1}$, cumulative advances have made it possible to synthesise peptides and polypeptides on cross-linked polymer supports through stepwise assembly of amino acid residues. Several synthetic problems were encountered with the heterogeneous divinylbenzene-cross-linked polystyrene system $^{2}$ (DVB-PS), which necessitated the development of polymer supports with optimum physicochemical and solvation properties. During the last decade, polymer supports with hydrophilic cross-linking agents have received much attention ${ }^{3}$. Systematic and quantitative studies of the polymer supports in solid phase synthesis led to the development of hydrophilic flexible supports in our laboratory ${ }^{4-8}$. The hydrophilicity and

*For correspondence

Abbreviations used ${ }^{21}$ : Boc-t-butyloxy carbonyl; DCC - dicyclohexylcarbodiimide; DCM dichloromethane; DCU - dicyclohexylurea; DIEA - N,N-diisopropylethylamine; DMSO - dimethyl sulphoxide; HOBt - 1-hydroxy benzotriazole; NMP - N-methyl pyrrolidone; TFA - trifluoroacetic acid. 
flexibility imparted by the cross-linking agent improved the solvation characteristics and enhanced the reactivity of the polymer-bound functional groups.

This paper describes the efficiency of a 2-mole percentage ethyleneglycol dimethacrylate-cross-linked polystyrene support (EGDMA-PS) ${ }^{9}$ for manual solid-phase peptide synthesis. Preparation and characterisation of the polymer support, its functionalisation and the syntheses of a few peptides including two biologically important sequences are also delineated. Here we have selected a few model peptides and two biologically important peptides - an 11-residue peptide ATP binding site of the CDC2 kinase ${ }^{10}$ and a nine-residue peptide $\beta 34-42$ corresponding to a portion of the hydrophobic terminus of the $\beta$-amyloid protein $\beta 1-42^{11}$ - for synthesis using the support.

\section{Experimental}

\subsection{Materials and methods}

Styrene, $t$-butylcarbasate, polyvinyl alcohol (mol. wt. 72000-100000), DCC, HOBt, DIEA, TFA, DVB and side-chain-protected amino acids were purchased from Aldrich Chemicals Co., USA. Other Boc amino acids were prepared according to Schnabel's procedure $^{12}$. AR grade solvents were used after distillation and purification according to literature procedures. Chloromethyl methyl ether (CMME) was prepared using literature procedure $^{13}$. The IR spectra were recorded on a Shimadzu 470 spectrophotometer using $\mathrm{KBr}$ pellets and the ${ }^{13} \mathrm{C}$ CP-MAS NMR measurements were carried on a Bruker 300MSL CP-MAS instrument. HPLC was performed using Shimadzu SPD-10A UV-Vis detector HPLC.

\subsection{Preparation of EGDMA and DVB-cross-linked styrene copolymer}

A mixture of styrene (22.46 ml, $98 \mathrm{~mol} \%)$, EGDMA ( $0.754 \mathrm{ml}, 2 \mathrm{~mol} \%)$, toluene $(10 \mathrm{ml})$ and benzoyl peroxide $(500 \mathrm{mg})$ was suspended in a solution of polyvinyl alcohol $(1.75 \mathrm{~g}$ dissolved in $175 \mathrm{ml}$ water) and kept mechanically stirred at $600 \mathrm{rpm}$ at a temperature of $85^{\circ} \mathrm{C}$. After $6 \mathrm{~h}$ the beaded resin was filtered, washed with hot water and soxhletted with acetone followed by methanol to remove linear polymers and low molecular weight products. The beads were meshed to $200-400$ range. Yield of the polymer obtained was $85 \%$.

For preparation of the divinylbenzene-cross-linked polystyrene (DVB-PS), the same procedure was employed and the yield polymer obtained was $70 \%$.

\subsection{Functionalisation of EGDMA-PS copolymer}

The EGDMA-cross-linked polymer $(1 \mathrm{~g})$ was refluxed with chloromethyl methyl ether $(6 \mathrm{ml})$ and freshly prepared $\mathrm{ZnCl}_{2}$ in THF $(0.3 \mathrm{ml})$ at $50^{\circ} \mathrm{C}$ for $4 \mathrm{~h}$. After reaction the resin was filtered, washed with THF, THF/ $\mathrm{H}_{2} \mathrm{O}$ and was soxhletted with THF. The chlorine capacity was estimated by pyridine fusion method ${ }^{14}$ and was found to be $1.63 \mathrm{mmol} \mathrm{Cl} / \mathrm{g}$.

\subsection{Attachment of the C-terminal amino acids to the polymer support}

2.4a Attachment of Boc-Phe: Boc-Phe (325 mg, $1.2 \mathrm{mmol})$ was dissolved in minimum quantity of ethanol and added aqueous $\mathrm{CsCO}_{3}$ till the $p \mathrm{H}$ of the solution was between 7 
and 8. The solution was coevaporated with benzene and the solid Boc-PheO-Cs salt was kept overnight under vacuum. The cesium salt of the Boc amino acid was dissolved in NMP (4 ml) and to this solution was added chloromethylated resin $(300 \mathrm{mg}, 0.48 \mathrm{mmol}$ $\mathrm{Cl})$. The mixture was kept at $50-60^{\circ} \mathrm{C}$ for $32 \mathrm{~h}$ with intermittent shaking. After reaction the resin was filtered, washed with $\mathrm{NMP}, \mathrm{NMP} / \mathrm{H}_{2} \mathrm{O}$ (1:1), methanol and dichloromethane (DCM). The Boc amino acid appended resin was dried under vacuum. Amino group capacity was determined by the picric acid method ${ }^{15}$ and was found to be quantitative $\left(1.30 \mathrm{mmol} \mathrm{NH}_{2} / \mathrm{g}\right)$.

2.4b Attachment of Boc-Ala: For appending Boc-Ala a procedure similar to that for Boc-Phe was adopted. Here, for $100 \mathrm{mg}$ of resin $(0.163 \mathrm{mmol} \mathrm{Cl})$ the amount of amino acid used was $75 \mathrm{mg}(0.40 \mathrm{mmol})$. The capacity of the resulting resin was estimated to be $1.45 \mathrm{mmol} \mathrm{NH}_{2} / \mathrm{g}$.

\subsection{Peptide synthesis}

2.5a Synthesis of peptides a-d: Boc-Phe resin $\left(100 \mathrm{mg}, 0.13 \mathrm{mmol} \mathrm{NH}_{2}\right)$ was placed in a solid-phase shaking vessel and the Boc group removed by treating with 30\% TFA in DCM (4 ml, $30 \mathrm{~min})$ followed by neutralisation with 5\% DIEA in DCM $(4 \mathrm{ml}, 2 \times 5)$. The resin was then filtered and washed with NMP $(2.5 \mathrm{ml}, 5 \times 1)$. The ninhydrin test was positive for the resin indicating the presence of free amino group. Subsequent amino acids were coupled to the Boc deprotected resin by the HOBt active ester method using NMP as the solvent. The active ester of the amino acid was prepared by reacting amino acid, HOBt and DCC (1:1:1) in NMP. After the removal of dicyclohexyl urea (DCU) by filtration, the filtrate was used for the coupling reaction. A two-fold molar excess of Boc amino acid was used in all the coupling steps. After each coupling the peptidyl resin was washed with $33 \% \mathrm{MeOH}$ in DCM to remove any DCU present. The progress of the coupling reaction was monitored by the semiquantitative ninhydrin test ${ }^{16}$. Finally, the synthesised peptides were cleaved from the support by exposing the peptidyl resin to neat TFA. The peptides were obtained as white powder.

2.5b Synthesis of peptide e: The Boc-Phe resin $\left(100 \mathrm{mg}, 0.13 \mathrm{mmol} \mathrm{NH}_{2}\right)$ was taken in a solid-phase reaction vessel and the peptide was synthesised by the same protocol employed in the synthesis of peptides a-d. For each coupling a two-fold molar excess of amino acid was taken. Double coupling was employed at all stages to ensure $100 \%$ completion of reaction. After cleavage, the amount of peptide obtained from $100 \mathrm{mg}$ of the peptidyl resin was $46 \mathrm{mg}(93 \%)$.

2.5c Synthesis of peptide $\mathbf{f}$ : Boc-Ala resin (100 mg, 0.145 $\mathrm{mmol} \mathrm{NH}_{2}$ ) was washed with DCM and the Boc group was removed followed by neutralisation. The active ester of the amino acid with HOBt was prepared in DMF and was used for the coupling reactions. The amount of free peptide obtained from $100 \mathrm{mg}$ of the peptidyl resin was $50 \mathrm{mg}(91 \%)$.

\subsection{Cleavage of peptide from the resin}

The peptidyl resin $(100 \mathrm{mg})$ was suspended in $100 \%$ TFA $(5 \mathrm{ml})$ containing thioanisole $(0.5 \mathrm{ml})$, ethanedithiol $(0.5 \mathrm{ml})$ and the mixture kept at room temperature for $12 \mathrm{~h}$. The resin was filtered using a sintered funnel and the filtrate was rotaevaporated to remove TFA. To the residue, cold ether $(10 \mathrm{ml})$ was added to precipitate the peptide. The 
precipitated peptide was washed thoroughly with ether to remove any contaminating agent.

\subsection{Swelling studies}

Solvation studies were carried out using a sintered crucible. The dry polymer $(1 \mathrm{~g})$ was placed in a sintered glass crucible (porosity 3) and the resin was equilibrated with the solvent for $24 \mathrm{~h}$. Excess solvent was removed by applying mild suction and the weight of the crucible with the swollen resin was determined. The process was repeated till a constant weight for the swollen polymer was obtained. A blank experiment was carried out with the empty crucible. Finally, the solvation of the polymer was calculated as the volume of the solvent absorbed by unit weight of dry resin $(\mathrm{ml} / \mathrm{g})$.

\section{Results and discussion}

\subsection{Preparation, characterisation and functionalisation of EGDMA-PS support}

The EGDMA-cross-linked polystyrene support (3) was prepared by the radical initiated suspension polymerisation of monomers styrene (1) and EGDMA (2) (scheme 1). The<smiles>C=Cc1ccccc1</smiles>

1<smiles>C=C(C)C(=O)OCCOC(=O)C(=C)C</smiles>

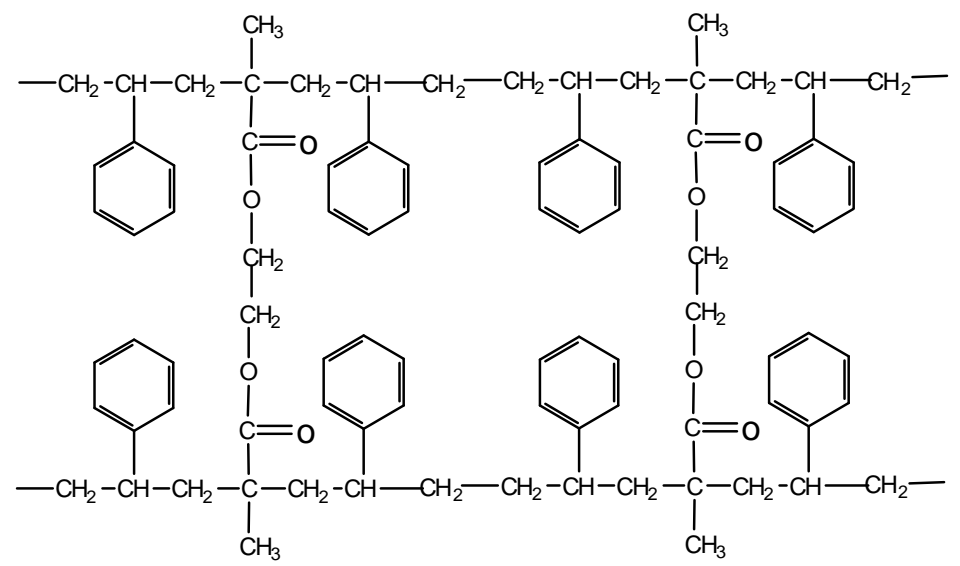

Scheme 1. 


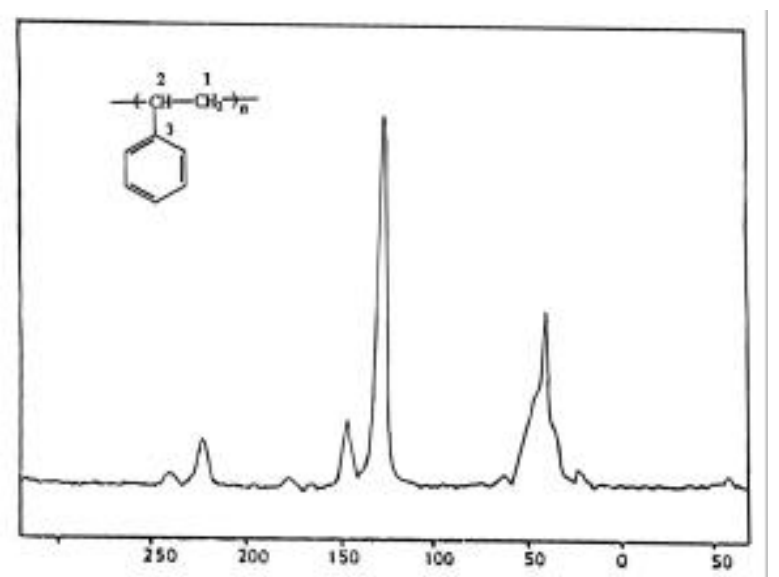

Figure 1. Solid state ${ }^{13} \mathrm{C} C P$ MAS NMR spectrum of EGDMA-PS copolymer.

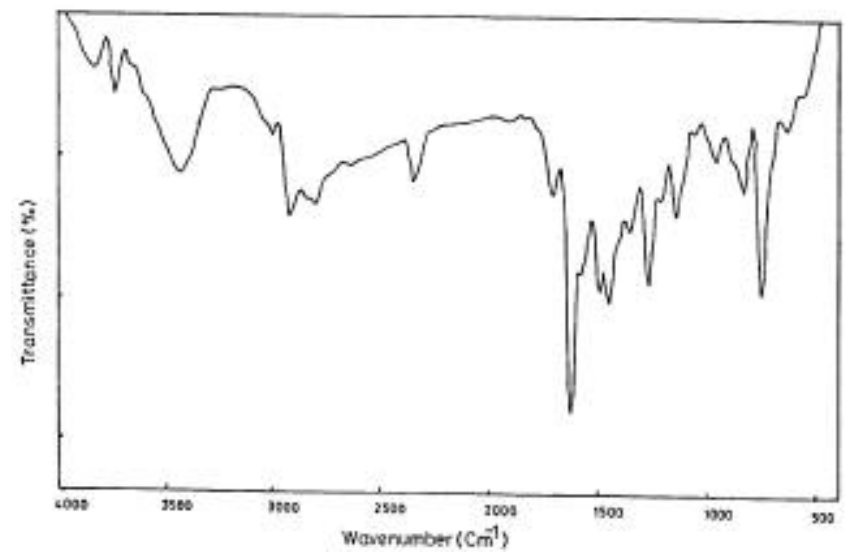

Figure 2. IR spectrum of EGDMA-PS copolymer.

polymer beads were characterised by ${ }^{13} \mathrm{C} \mathrm{CP}$-MAS NMR and IR spectra. The ${ }^{13} \mathrm{C} \mathrm{CP}$ MAS NMR spectrum (figure 1) exhibited an intense peak at $130.6 \mathrm{ppm}$ corresponding to the aromatic carbon of the styrene and a small peak at $148 \cdot 1 \mathrm{ppm}$ arising from the $\mathrm{C}_{3}$ carbon of styrene. The methylene carbons of the polymer backbone gave a singlet at $42.7 \mathrm{ppm}$. The IR spectrum of PS-EGDMA resin showed a sharp band $1720 \mathrm{~cm}^{-1}$ corresponding to the ester carbonyl group of the cross-linking agent (figure 2). The scanning electron micrograph (figure 3) showed the smooth spherical surface of the beaded polymer.

The cross-linked polymer with 200-400 mesh size was functionalised via FriedelCrafts chloromethylation reaction using chloromethyl methyl ether in presence of anhydrous $\mathrm{ZnCl}_{2}$ as catalyst at $50^{\circ} \mathrm{C}$ (scheme 2). The IR spectrum of the chloromethylated resin showed characteristic $\mathrm{C}-\mathrm{Cl}$ stretching at $680 \mathrm{~cm}^{-1}$. The capacity of the chloromethyl resin was estimated by Volhard's titrimetric method and found to be $1.63 \mathrm{mmol} \mathrm{Cl} / \mathrm{g}$. 


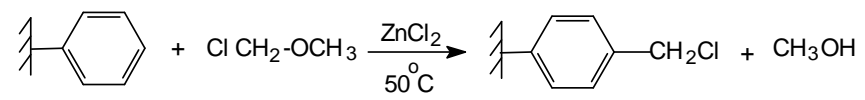

3

4

Scheme 2.

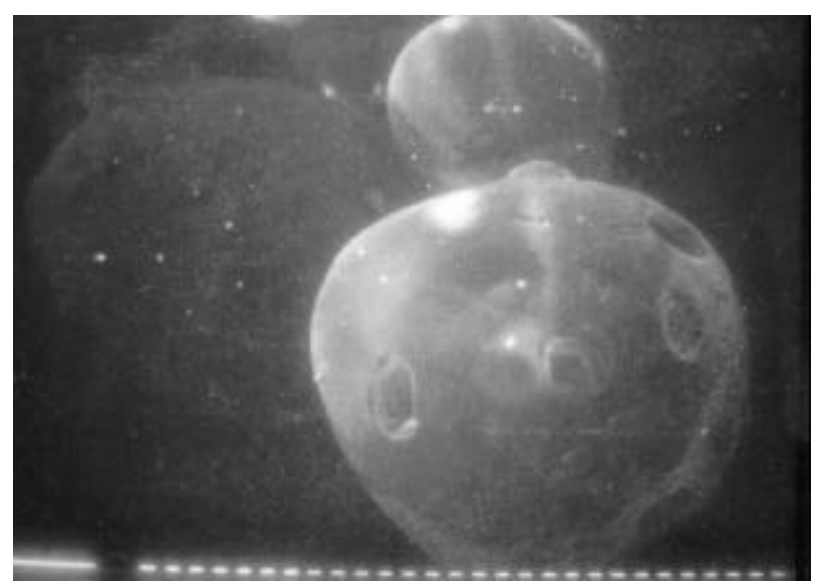

Figure 3. Scanning electron micrograph of the beaded 200-400 mesh EGDMA-PS copolymer.

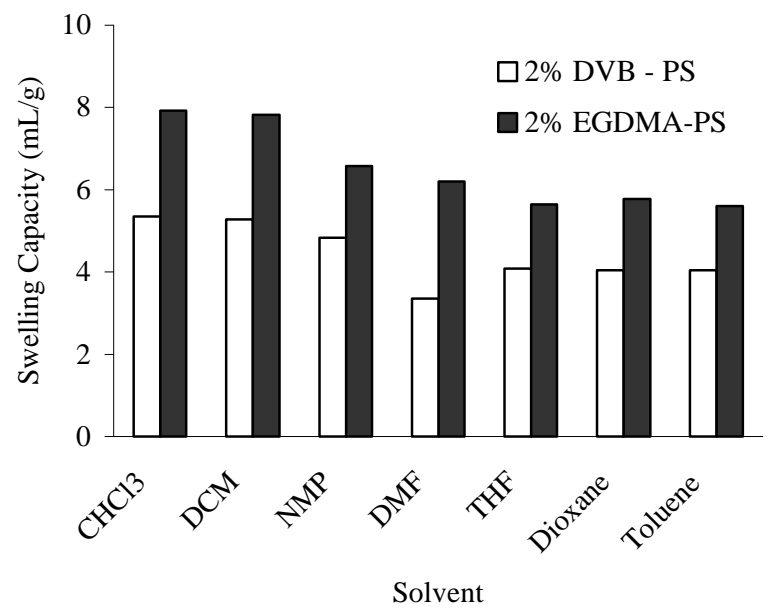

Figure 4. Comparative swelling capacities of the 2\% EGDMA-PS and 2\% DVB-PS copolymers.

\subsection{Swelling studies}

Swelling is one of the important and necessary criteria for efficient support in solid-phase peptide synthesis ${ }^{17}$. Solvation of the polymer backbone chain might be significant in the different synthetic steps. Comparative swelling behaviour of the 2\% EGDMA-PS and 
Table 1. Details of the peptides synthesised using EGDMA-PS resin.

\begin{tabular}{llcc}
\hline Peptide & Amino acid sequence & $R_{f}^{*}$ value & $\begin{array}{c}\text { Yield of the } \\
\text { crude peptide (\%) }\end{array}$ \\
\hline a & V V F & 0.92 & 95 \\
b & L V V F & $0 \cdot 90$ & 95 \\
c & A L V V F & $0 \cdot 86$ & 94 \\
d & I A L V V F & $0 \cdot 83$ & 94 \\
e & K I G E G T Y G V V F & - & 93 \\
f & L M V G G V V I A & - & 91 \\
\hline
\end{tabular}

*In the solvent system pyridine-acetic acid-water (50:30:20)

$2 \%$ DVB-PS in a variety of solvents is given in figure 4. The EGDMA-PS resin swells both in polar and nonpolar solvents. This enhanced solvation of the EGDMA-crosslinked matrix may facilitate the accessibility of the soluble reagents to the polymer-bound functionalities which inturn can increase the yield and the purity of the synthesised peptides.

\subsection{Synthesis of peptides}

3.3a Synthesis of the peptides a-e: The first amino acid Boc-Phe was attached to the chloromethylated resin $(1.63 \mathrm{mmol} \mathrm{Cl} / \mathrm{g})$ by Gisin's cesium salt method ${ }^{18}$. The peptides (table 1) were assembled by the manual solid-phase method using Boc amino acid strategy ${ }^{19}$. The syntheses of model peptides a-d and the biological peptide ATP binding site of the $\mathrm{CDC} 2$ kinase $\mathbf{e}$ were carried out by DCC-mediated HOBt active ester coupling method. Boc deprotection was done by treatment with 30\% TFA in DCM followed by neutralisation with 5\% DIEA in DCM. The peptide chain was built towards the amino terminus by the stepwise addition of Boc amino acids. In each step, the HOBt active ester of the Boc amino acid was employed and NMP was used as solvent. The extent of Boc deprotection and amino acylation reactions were monitored by Kaiser's test ${ }^{18}$. A two-fold molar excess of Boc amino acid was used for the coupling reaction. Double coupling was employed for all the peptides. The general protocol for the synthesis starting from $100 \mathrm{mg}$ first attached resin is as follows.

(1) DCM wash $(2.5 \mathrm{ml}, 5 \times 1)$.

(2) Deprotection using 30\% TFA in DCM (4 ml, $30 \mathrm{~min})$.

(3) DCM wash $(2.5 \mathrm{ml}, 5 \times 1)$.

(4) Neutralisation using 5\% DIEA in DCM $(4 \mathrm{ml}, 2 \times 5)$.

(5) $\mathrm{NMP} / \mathrm{DMF}$ wash $(2 \cdot 5 \mathrm{ml}, 5 \times 1)$.

(6) Coupling with Boc amino acid HOBt ester in NMP/DMF, 2 equivalent excess (45 min).

(7) Addition of DMSO, (15\% of total volume of NMP/DMF used for coupling solvent), (15 min).

(8) Addition of DIEA (3.8 meq.), (5 min).

(9) Methanol DCM mixture (33:67), wash $(2.5 \mathrm{ml}, 5 \times 1)$.

(10) Repeat steps (1)-(9). 


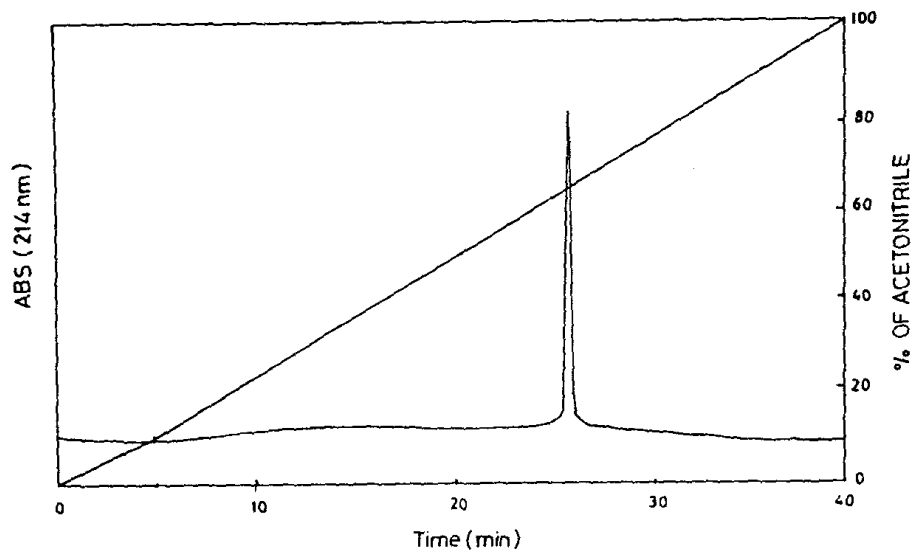

Figure 5. Analytical HPLC of the peptide e. Conditions: Solvent A-water containing $0.1 \%$ TFA; solvent $\mathrm{B}-$ acetonitrile containing $0.1 \%$ TFA. The gradient used was $0-10 \% \mathrm{~B}$ in $10 \mathrm{~min}, 100 \% \mathrm{~B}$ at $40 \mathrm{~min}$. Flow rate $1 \mathrm{ml} / \mathrm{min}$; detection $214 \mathrm{~nm}$.

The final cleavage of the peptide was achieved by the treatment with $100 \%$ TFA. Yield of the crude peptides was $\sim 95 \%$ by weight. The purity of the crude peptides was checked by TLC and HPLC. All model peptides showed a single spot in TLC in the solvent system pyridine-acetic acid-water (50:30:20). $R_{f}$ values are given in table 1 . The HPLC profile of the biological peptide ATP binding site of the CDC2 kinase e showed only one peak indicating the high purity of the peptide (figure 5). The high yield (93\%) of the synthesised peptide $\mathbf{e}$ compared to the earlier reports ${ }^{10}$ brings to light the efficiency of EGDMA-PS support.

3.3b Synthesis of $\beta$ 34-42 (f): The C-terminal amino acid Boc-Ala was attached as benzyl ester to the chloromethylated resin $(1.63 \mathrm{mmol} \mathrm{Cl} / \mathrm{g})$. The peptide chain was built by sequentially extending it toward the amino terminus. The general protocol of the synthesis was same as the synthesis of the peptides a-e, except the solvent NMP was replaced by DMF due to incomplete couplings in NMP. The final cleavage of the peptide from the resin was effected by TFA in the presence of thioanisole as the scavenger. The crude peptide was obtained in $>90 \%$ yield. The HPLC profile of peptide $\mathbf{f}$ is given in figure 6.

Purity of the peptide $\mathbf{f}$ was a little bit less when compared to $\mathbf{e}$, this may be due to the sequence-dependent problem of peptide $\mathbf{f}$. In the synthesis of the peptide $\mathbf{f}$ some of the couplings were found to be difficult, while in the case of peptide $\mathbf{e}$ all the coupling steps proceeded more or less smoothly. Peptide $\mathbf{f}$ is a hydrophobic, antiparallel $\beta$-sheeted peptide, where there is the possibility of aggregation of peptide chains ${ }^{11}$. Aggregation of the resinopeptide, was a major problem observed in the synthesis of hydrophobic, $\beta$ sheeted peptides in conventional solid-phase peptide synthesis ${ }^{20}$ and this has been overcome to some extent by the use of the hydrophilic flexible supports developed in our $\mathrm{lab}^{7}$. During the synthesis of peptide $\mathbf{f}$ on EGDMA-PS resin, coupling reactions between Gly and Gly at positions 37-38, and Val and Gly at 36-37 in the sequence, were difficult 


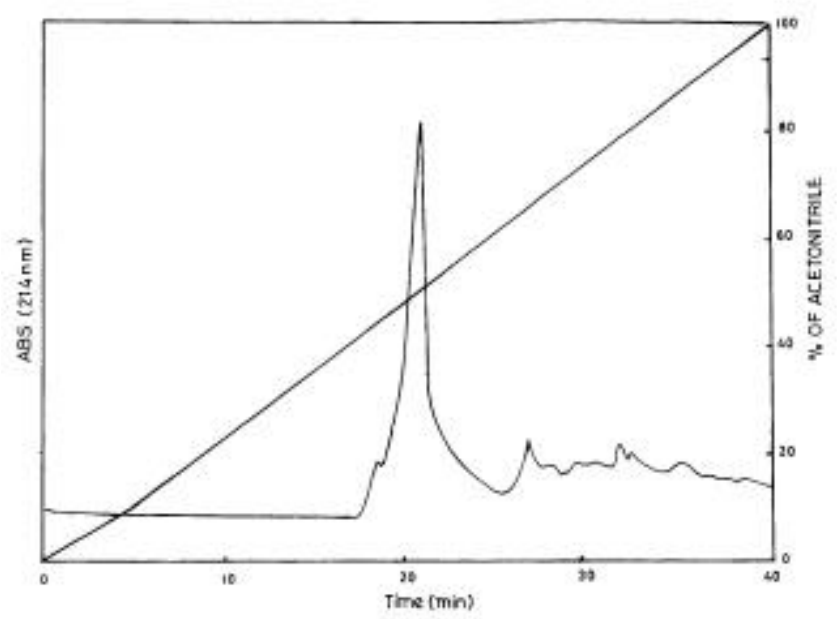

Figure 6. Analytical HPLC of the peptide f. Conditions: Solvent A-water containing $0.1 \%$ TFA; solvent $\mathrm{B}-$ acetonitrile containing $0.1 \%$ TFA. The gradient used was, $0-10 \% \mathrm{~B}$ in $10 \mathrm{~min}, 100 \% \mathrm{~B}$ at $40 \mathrm{~min}$. Flow rate $1 \mathrm{ml} / \mathrm{min}$; detection $214 \mathrm{~nm}$.

and the Kaiser test was negative only after two and three couplings respectively. In all other cases the test was negative after the first coupling itself. We tried to synthesise this difficult sequence peptide $\mathbf{f}$ on a $2 \%$ cross-linked DVB-PS resin and the couplings at Gly-Gly and Val-Gly were not complete even after five couplings. This difficulty in coupling may be due to the aggregation of the pendant peptide chains. Therefore, we have not carried out the synthesis of peptide $\mathbf{f}$ with DVB-PS support. The relatively high purity of the peptide $\mathbf{f}$ reveals that the aggregation problem is reduced in the case of the EGDMA-PS support. This may be attributed to the flexibility imparted by the EGDMA cross-links to the polymer support.

\section{Conclusion}

Four model peptides and two biologically important sequences were synthesised in good yields and with relatively high purities using a 2\% EGDMA-cross-linked polystyrene resin. The EGDMA-PS copolymer was prepared by suspension polymerisation and functionalised by chloromethylation. The copolymer has shown an excellent swelling character with a hydrophobic-hydrophilic balance. HPLC profiles showed the high purities of the peptides synthesised. Further, a relatively high capacity resin can be used for a cost-effective method for manual solid-phase peptide synthesis using Boc chemistry. The resin is very efficient for peptide synthesis including that of hydrophobic difficult-sequence peptides.

\section{Acknowledgements}

The authors thank the Department of Science and Technology, New Delhi for financial support to KSD, and the Council of Scientific and Industrial Research, New Delhi for fellowship to PKA. 


\section{References}

1. Merrifield R B 1963 J. Am. Chem. Soc. 852149

2. Pillai V N R and Mutter M 1982 Top. Curr. Chem. 106119

3. Kempe M and Barany G 1996 J. Am. Chem. Soc. 1187083

4. Beena M and Pillai V N R 1993 Indian J. Technol. 31302

5. Renil M, Nagaraj R and Pillai V N R 1994 Tetrahedron 506681

6. Varkey J T and Pillai V N R 1998 J. Peptide Res. 5149

7. Krishnakumar I M and Beena M 1998 Macromolecules new frontiers. Proceedings of the IUPAC International Symposium on Advances in Polymer Science and Technology, vol. 1, p. 461

8. Ajikumar P K and Devaky K S 1999 Proceedings of the 86th Session of Indian Science Congress. Part III. Young Scientists Abstracts, p. 20

9. Ajikumar P K and Devaky K S 1999 Proceedings of the 11th Session of Kerala Science Congress, p. 42

10. Mendre C, Sarrade V and Calas B 1992 Int. J. Peptide Protein. Res. 39278

11. Hendrix J C, Havelson K J, Jarrett J T and Lansbury P T 1990 J. Org. Chem. 554517

12. Schnabel E 1967 Anal. Chem. 702188

13. Marvel C S and Porter P K 1967 Organic Synthesis Collection of Volumes 2nd edn (New York: John Wiley \& Sons) vol. 1, p. 377

14. Stewart J M and Young J D 1984 Solid phase peptide synthesis 2nd edn (Rockford, IL: Pierce Chemical Co) p. 54

15. Gisin B F 1972 Anal. Chem. Acta 58248

16. Kaiser E, Colescott R L, Bossinger C D and Cook P I 1970 Anal. Biochem. J4 595

17. Fields G B and Fields C G 1991 J. Am. Chem. Soc. 1134202

18. Gisin B F 1973 Helv. Chem. Acta 561476

19. Barany G and Merrifield R B 1979 The peptides (eds) E Gross and J Meienhofer (NewYork: Academic Press), vol. 2, pp 1-284

20. Kent S B H 1988 Annu. Rev. Biochem. 3795

21. Abbreviations used according to the IUPAC-IUB Commission of Biochemical Nomenclature in Eur. J. Biochem. 19841389 and J. Mol. Chem. 1989214264 